\title{
Hyperpyrexia in spinal injury patients
}

\author{
A Essiet $\mathrm{MB} \mathrm{BS}^{1}$, O Onuba $\mathrm{FRCS}^{2 *}$ \\ ${ }^{1}$ Senior Resident, ${ }^{2}$ Consultant Orthopaedic Surgeon, Department of Surgery, University of \\ Calabar Teaching Hospital, PMB 1278, Calabar, Nigeria.
}

We studied 13 spinal injury patients who had hyperpyrexia during an 18 month period (September 1984-March 1986) to discover if differences existed in the core temperature of patients with tetraplegia and those with paraplegia, and the contribution of these differences to the final outcome. Children were excluded from this study as well as patients with any sign of infection on first admission, patients with multiple injuries, and those referred from peripheral hospitals more than one week after injury. Patients with tetraplegia $(\mathrm{C} 3-\mathrm{C} 7)$ had persistently high and uncontrollable core temperatures (average $39.5^{\circ} \mathrm{C}$ ) while those with paraplegia (T4-L5) showed lower core temperatures which were still high (average $38.1^{\circ} \mathrm{C}$ ). The difference in the average high core temperature $\left(1.4^{\circ} \mathrm{C}\right)$ is statistically significant. The lowest average core temperatures were about the same in tetraplegics and paraplegics (just over $35^{\circ} \mathrm{C}$ ). Four patients died: 3 tetraplegics and one paraplegic. Antipyretic analgesics were ineffective in reducing the high core temperatures.

Key words: hyperpyrexia; spinal cord injury; core temperature; paraplegia, tetraplegia.

\section{Introduction}

Partial poikilothermia is a well known condition among spinal injury patients. ${ }^{1-3}$ This is because there is dissociation in the temperature pathways, ie surface cold/warm receptors of the skin/mucous membrane and afferent transmitters to the hypothalamus, and the efferent transmitter systems which mediate impulses from cerebral stations to the periphery via descending pathways. This loss of temperature control is particularly evident in ambient air temperatures above and below $26.5^{\circ} \mathrm{C},{ }^{4}$ as is shown in animal experiments and clinical trials. Therefore in a hot humid tropical climate patients with spinal transection will exhibit a high degree of poikilothermia.

\section{Method}

Thirteen adult patients, 10 males and 3 females were involved in the study. Nine of the patients were road accident victims

\footnotetext{
*Correspondence
}

while 4 were hit by falling trees. Each patient was seen by either of the authors within 24 hours of admission to ascertain the level of injury clinically and to correlate this with any $\mathrm{x}$-ray findings. Two temperature readings were taken each day at $6 \mathrm{am}$ and $4 \mathrm{pm}$ respectively, each recording consisting of the average of oral and rectal thermometer readings at the time. Any slight errors in the temperature recordings were compensated by averaging the readings over a long period and by the fact that spinal injury patients always received acute nursing care during the early stages. Useful temperature records were taken up to one month after admission, or until the patient died, and were stopped if the patient developed any sign of infection. One paraplegic died after 3 days and a tetraplegic left hospital against medical advice after 8 days but their average core temperatures were included. If temperatures exceeded $39^{\circ} \mathrm{C}$, one or other of the following antipyretic regimes was given: (1) $\mathrm{i} / \mathrm{m} 50 \mathrm{mg}$ Chlorpromazine once daily; (2) $\mathrm{i} / \mathrm{m} 50 \mathrm{mg}$ Chlorpromazine plus i/v cold saline infusion. Throughout the period, 
ambient room temperatures were between $22^{\circ} \mathrm{C}$ and $32^{\circ} \mathrm{C}$.

\section{Results}

A total of 13 fresh spinal injury patients were included during the 18 month studyothers were excluded because they were children (very few), had multiple injuries or had been transferred from peripheral hospitals later than one week after injury, usually with bed sores and respiratory or urinary tract infection. Their ages ranged from 17 to 54 years. Seven of the patients sustained injuries above C6 spine and were tetraplegic while 6 sustained injuries in the thoracic or lumbar spine and were paraplegic (Table I). In analysing the temperature recordings, $36{ }^{\circ} \mathrm{C}-37.5^{\circ} \mathrm{C}$ was taken as the normal range of average core temperature in the locality. Any temperature above $37.5^{\circ} \mathrm{C}$ was regarded as high and below $36^{\circ} \mathrm{C}$ was regarded as low. The highest core temperature of $40.5^{\circ} \mathrm{C}$ was recorded in a tetraplegic and most of the other tetraplegics recorded average high core temperate of $39.5^{\circ} \mathrm{C}$ especially at $4 \mathrm{pm}$ (Fig 1 ). On the other hand the average high core temperature in paraplegics was $38.1^{\circ} \mathrm{C}$ (also $4 \mathrm{pm}$ reading), a difference of $1.4^{\circ} \mathrm{C}$. The average low core temperature in tetraplegics was $35.6{ }^{\circ} \mathrm{C}$, while in paraplegics it was $35.3^{\circ} \mathrm{C}$, showing an insignificant difference of $0.3^{\circ} \mathrm{C}$ especially when ambient temperatures were taken into account (Fig 2).

Four deaths occurred-3 tetraplegics after 15, 16 and 30 days respectively of admission to hospital, while one paraplegic died 5 days after admission, probably from fat embolism. The antipyretic drugs did not cause any significant reduction in the average high core temperatures over $39^{\circ} \mathrm{C}$.

\section{Discussion}

It has been clearly shown that tetraplegic patients have a higher core temperature in the heat and a lower core temperature in the cold. The inability to maintain a constant core temperature is attributed to the lack of efficient method of vasoconstriction, vasodilatation and sweating. ${ }^{5,6,1,4}$

In this series, the maximum and minimum core temperatures of 7 tetraplegics and 6 paraplegics were measured during the acute phase of the first month of injury. We found that tetraplegics maintained a higher average core temperature $\left(39.5^{\circ} \mathrm{C}\right)$ than paraplegics $\left(38.1^{\circ} \mathrm{C}\right)$, a significant difference of $1.4^{\circ} \mathrm{C}$. But most tetraplegic and paraplegic patients maintained identical average low

Table I Analysis of spinal injury

\begin{tabular}{|c|c|c|c|}
\hline $\begin{array}{l}\text { Level of injury/clinical } \\
\text { diagnosis }\end{array}$ & $\begin{array}{l}\text { High temp. } \\
{ }^{\circ} \mathrm{C}\end{array}$ & $\begin{array}{l}\text { Low temp. } \\
{ }^{\circ} \mathrm{C}\end{array}$ & Outcome \\
\hline $\begin{array}{l}\text { Tetraplegia dislocation } \\
\text { at } \mathrm{C} 3 / 4\end{array}$ & $39.5^{\circ} \mathrm{C}$ & $35^{\circ} \mathrm{C}$ & Died after 30 days in hospital \\
\hline Paraplegia at $\mathrm{T} 4$ & $37.5^{\circ} \mathrm{C}$ & $36^{\circ} \mathrm{C}$ & Died after 3 days in hospital \\
\hline Tetraplegia at $\mathrm{C} 4 / 5$ & $39.5^{\circ} \mathrm{C}$ & $36.5^{\circ} \mathrm{C}$ & $\begin{array}{l}\text { Left hospital against medical advice after } \\
1 \text { week }\end{array}$ \\
\hline Tetraplegia at $\mathrm{C} 3-5$ & $39.2^{\circ} \mathrm{C}$ & $35^{\circ} \mathrm{C}$ & Left hospital after 15 months \\
\hline Paraplegia at $\mathrm{T} 7$ & $39.1^{\circ} \mathrm{C}$ & $35.5^{\circ} \mathrm{C}$ & Discharged after 47 days in hospital \\
\hline Paraplegia at $\mathrm{L} 4 / 5$ & $37^{\circ} \mathrm{C}$ & $35.2^{\circ} \mathrm{C}$ & Discharged home after 22 days in hospital \\
\hline Paraplegia at $\mathrm{T} 2 / 3$ & $39^{\circ} \mathrm{C}$ & $35^{\circ} \mathrm{C}$ & Discharged home \\
\hline Tetraplegia at $\mathrm{C} 6 / 7$ & $38^{\circ} \mathrm{C}$ & $36^{\circ} \mathrm{C}$ & Discharged after 120 days in hospital \\
\hline Tetraplegia C6 & $40^{\circ} \mathrm{C}$ & $36^{\circ} \mathrm{C}$ & Died after 16 days in hospital \\
\hline $\begin{array}{l}\text { Paraplegia dislocation } \\
\text { at L4 }\end{array}$ & $38^{\circ} \mathrm{C}$ & $35.5^{\circ} \mathrm{C}$ & Discharged after 44 days in hospital \\
\hline Tetraplegia at $\mathrm{C} 7$ & $40.5^{\circ} \mathrm{C}$ & $35^{\circ} \mathrm{C}$ & Discharged after 7 months in hospital \\
\hline Paraplegia at $\mathrm{T} 10-11$ & $38.2^{\circ} \mathrm{C}$ & $35^{\circ} \mathrm{C}$ & Discharged after 80 days in hospital \\
\hline Tetraplegia at $\mathrm{C} 5-7$ & $39.5^{\circ} \mathrm{C}$ & $36^{\circ} \mathrm{C}$ & Died after 15 days in hospital \\
\hline
\end{tabular}




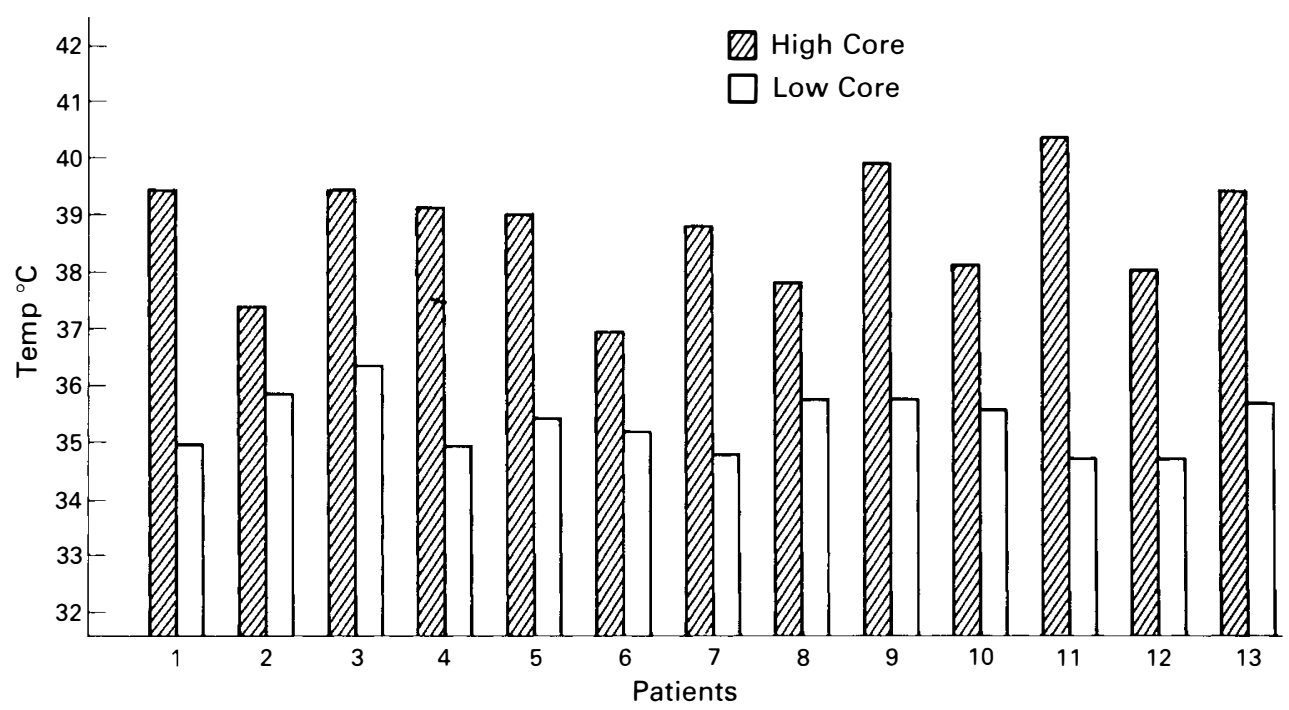

Figure 1 Average high and low core temperatures

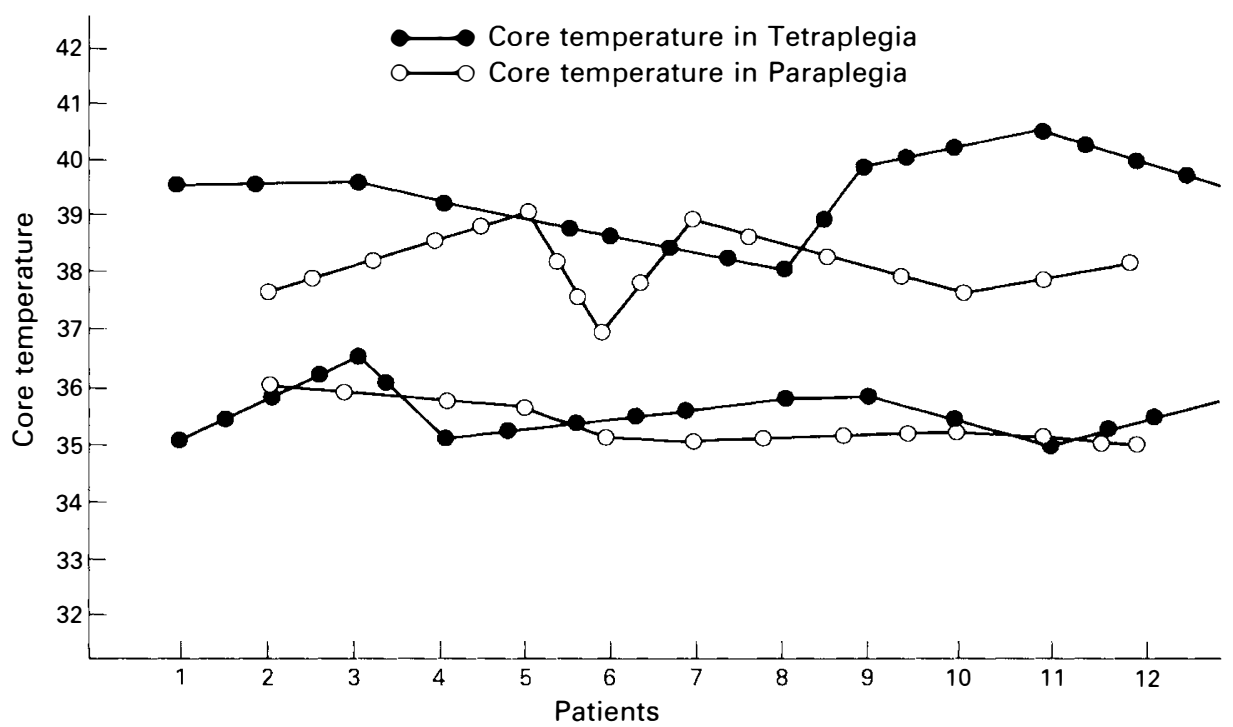

Figure 2 Average core temperature differences

core temperatures (just over $35^{\circ} \mathrm{C}$ ). The use of antipyretic measures to bring down hyperpyrexia in a few earlier patients was ineffective and was abandoned. Indeed, the average core temperatures remained persistently high in the first 2 tetraplegic deaths despite the use of Chlorpromazine and cold saline infusion and no clinical evidence of infection. The difference in the average high core temperature between the high and low spinal transections may be explained by the fact that the temperature gradient for heat transfer between the skin and ambient air temperature is reduced in paraplegics, since a substantial part of their body surface still receives efferent temperature regulation. But in tetraplegics the entire body surface loses complete vasomotor control or sometimes may have only a small surface areathe face receiving temperature efferents. 
More deaths occurred in tetraplegics, (3 out of 4), probably as a result of the hyperpyrexia. We believe none of the deaths was related to overt post traumatic infection.

It is unlikely that hyperpyrexia persists for a long time after spinal shock. Clinical experiments by some authors ${ }^{3,7}$ confirm that paraplegic patients possess the ability to stabilise their body temperatures with ambient room temperatures after about 6 months from injury. Since hypothermia reduces the
$\mathrm{O}_{2}$ requirements of living tissue (and hence metabolic requirements) the usefulness of nursing spinal injury patients in air conditioned rooms needs to be studied. The cost would be prohibitive in the impoverished Third World and perhaps adaptive thermoregulatory mechanisms may be lost. But a prospective study of a large series of patients nursed quite early in air conditioned rooms could suggest the solution to hyperpyrexia.

\section{References}

1 Guttman L, Silver J, Wyndham (1958) Thermoregulation in spinal man. Physiol 142: 406-419.

2 White JC (1959) Injuries to the cervical cord. J Bone Joint Surg 41A: 11-19.

3 Downey JA, Chiodi HP, Darling RC (1967) Central temperature regulation in the spinal man. J Applied Physiol 22(1): 91-94.

4 Attia M, Engel P, Hildebraudt G (1982) Assessment of thermal comfort parameters using a behavioural indicator with special reference to physically disabled. In: Hildebraudt G, Hensel H, editors (1982) Biological Adaption. Thieme Verlag, Stuttgart: 212-215.

5 Pollock LJ, Boshes B, Chor H, Finkebman I (1951) Defects of regulatory mechanism of autonomic functions in injuries to spinal cord. $J$ Neurophys 14: 85-93.

6 Downey JA, Huckaba CE, Myers SJ, Darling RC (1973) Thermoregulation in the spinal man. J Appl Physiol 34(6): 790-794.

7 Attia M, Engel P (1983) Thermoregulatory set point in patients with spinal cord injuries (spinal man). Paraplegia 21: 233-248. 